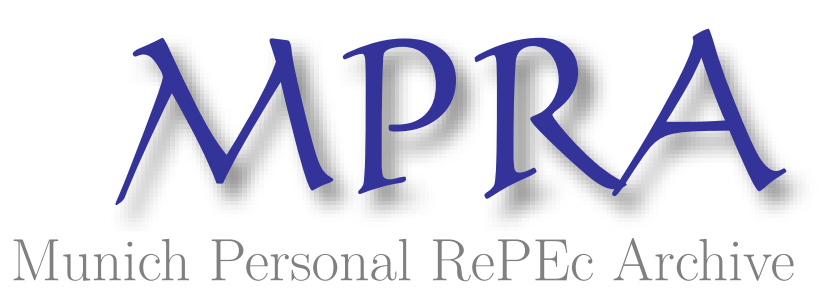

\title{
Education and Political Engagement
}

Le, Kien and Nguyen, My

2019

Online at https://mpra.ub.uni-muenchen.de/110964/

MPRA Paper No. 110964, posted 08 Dec 2021 06:31 UTC 


\title{
Education and Political Engagement
}

\author{
Kien Le \& My Nguyen ${ }^{\dagger}$
}

\begin{abstract}
While the robust and positive association between education and political engagement has been widely documented, the direct causal link is still a subject of debate. This study contributes to the ongoing debate by examining whether there exists a causal effect of education on political engagement. Exploiting the plausibly exogenous variation in education induced by the compulsory schooling reforms across 39 countries, we find that education cultivates political interest, promotes the acquisition of political knowledge, and fosters supportive attitudes towards political freedoms. Nevertheless, the better educated are no more likely to vote in elections nor adopt any specific position in the left-right political spectrum.
\end{abstract}

JEL codes: I20, H40, H80

Keywords: Political Engagement, Education, Compulsory Schooling.

$\dagger$ Faculty of Economics and Public Management, Ho Chi Minh City Open University. Le: kien.le@ou.edu.vn. Nguyen (corresponding author): my.ngt@ou.edu.vn. 


\section{Introduction}

Political engagement refers to emotional and cognitive involvement in political matters, such as political knowledge, interest, opinions, or attitudes; and encompasses citizens' actions to influence decisions of public officials such as voting, protesting, or political membership (Verba et al., 1995; Brady, 1999; Zukin et al., 2006; Barrett and Brunton-Smith, 2014). Social scientists have long embraced the belief that democracy is founded on an educated population (Smith, 1776; Friedman, 1962; Dahl, 1973). Therefore, political engagement as a return to education remains a focal point of social science research for years. Although the correlation between educational attainment and political engagement is documented in various settings (Wolfinger and Rosenstone, 1980; Putnam, 1995), a fewer number of attempts have been made to account for the endogeneity of education and establish a causal relationship. Consequently, two competing explanations for the positive association between education and political engagement have been developed. The 'cause' view states that education directly causes political engagement by teaching citizens the knowledge and behaviors needed for understanding politics, identifying political preferences, and pursuing political interests. ${ }^{1}$ Meanwhile, the 'sorting-mechanism' view argues that education simply takes credit for other factors that simultaneously determine educational attainment and political engagement, such as social network position and cognitive ability. ${ }^{2}$

In this paper, we investigate the extent to which educational attainment influences individuals' political engagement in 39 countries across the globe. The study brings four contributions to the literature. First, we contribute to the unresolved debate on the causal link between education and political engagement by exploiting the exogenous changes in educational years induced by the compulsory schooling reforms to identify the causal effects. Second, our study complements prior works by rigorously examine various dimensions of political engagement, including political interest, knowledge, attitude, voting, and affiliation. Third, instead of

${ }^{1}$ For studies supporting the 'cause' view, please see Wolfinger and Rosenstone (1980), Rosenstone and Hansen (1993), Niemi and Junn (1998), Torney-Purta et al. (1999), Galston (2001), Dee (2004), Milligan et al. (2004), Sondheimer and Green (2010), Mayer (2011).

2 For studies supporting the 'sorting-mechanism' view, please refer to Luskin (1990), Nie et al. (1996), Herrnstein and Murray (1994), Kam and Palmer (2008), Highton (2009), Berinsky and Lenz (2011), Pelkonen (2012), Persson (2013). 
focusing on one single country, we study the political return to education for a large sample of 39 countries. The wide coverage helps to reduce the threats to external validity of our estimates. Finally, by documenting the positive impacts on political interest, knowledge, and attitude, we supplement prior studies on the non-pecuniary return to education. ${ }^{3}$

To examine the relationship between educational attainment and political engagement, we employ the Role of Government module of the International Social Survey Programme. The dataset provides a wide range of political opinions, attitudes, and behaviors for a large number of countries. In terms of identification, we exploit the plausibly exogenous changes in educational years induced by the compulsory education reforms, within an Instrumental Variable framework. The reforms raise the mandatory years of education by one or more years for cohorts born after a given year while those who just missed the age cut-off of the law are not affected. As a result, individuals born two or three years apart are subject to different levels of compulsory schooling, which ultimately affects their educational attainment.

Our study reaches the following findings. First, an additional year of education raises the individual's interest in politics by 6.7 percentage points and increases the individual's selfperceived political knowledge by 8.5 percentage points. Second, education further fosters supportive attitudes towards political freedoms. Particularly, a one-year increase in education raises the probability of the individual endorsing the organization of public meetings and marches-demonstrations to protest against the government by 6.0 and 8.0 percentage points, respectively. The individual is also 10.4 and 6.2 percentage points more likely to support revolutionists' organization of public meetings and book publication to express their views. Nevertheless, the better educated are no more likely to vote in the election nor adopt any specific position in the left-right political spectrum.

Although we do not find the educational effects on political affiliation and voting behavior, extra schooling still fosters political interest, political knowledge, and supportive attitudes towards political freedoms. Therefore, the role of education in a representative democracy may

${ }^{3}$ For example, education has been documented to improve one's own health and well-being (Silles, 2009), enhance the health outcomes of their children (Le and Nguyen, 2020), and reduce criminal behavior (Lochner and Moretti 2004). 
not lie with increasing the quantity of citizens' political involvement (voting and affiliation) but lie with enhancing the quality of their involvement (interest, knowledge, attitudes). To an extent that a fully informed electorate can improve the quality of democracy, our findings underscore the positive externalities of education and justify government interventions in the provision and financing of education.

The paper proceeds as follows .Section 2 reviews related literature. Section 3 presents a description of the data. Section 4 outlines the empirical strategy to estimate the relationships of interest. Section 5 discusses our estimating results. Section 6 concludes the paper.

\section{Literature Review}

The robust and positive association between education and political engagement has been widely documented. To explain this strong correlation, two competing views have been developed. First, the 'cause' view, build on the civic education hypothesis, argues that education can expand individuals' capacity by teaching citizens the knowledge and behaviors needed for understanding politics, identifying political preferences, and pursuing political interests. To put it differently, this hypothesis argues that education can stimulate political engagement by lowering both cognitive and material costs to become politically involved (Wolfinger and Rosenstone, 1980; Rosenstone and Hansen, 1993). For example, education not only equips citizens with basic literacy skills to have minimal understanding of the political system but also imparts political knowledge and familiarity that help in navigating the political world (Niemi and Junn, 1998; Torney-Purta et al., 1999; Galston, 2001).

In contrast, the 'sorting-mechanism' view, build on the social network and political meritocracy hypotheses, argues that education does not actually stimulate but simply predict political involvement by serving as a proxy for other factors. The social network hypothesis believes that education can influence political engagement by determining an individual's social network position (Nie et al., 1996). In other words, education serves as a sorting system in which more educated individuals tend to posit closer to the center of important social and political networks. For examples, factors such as parents' political orientation and participation not only affect their children's political engagement but also determine 
educational attainment (Westholm, 1999; Achen, 2002; Andolina, 2003). Also build on the 'sorting-mechanism', the political meritocracy hypothesis believes that both education and political engagement are produced by cognitive ability. In other words, individuals with higher innate ability are more likely to proceed further in school and also to engage in politics at higher rates. Therefore, once the cognitive ability is taken into account, education should have no impact on political engagement (Luskin, 1990; Herrnstein and Murray, 1994).

Recently, empirical studies have employed more sophisticated methods to examine whether there exists a causal effect of education on political engagement (the 'cause' view) or education is simply a proxy for other factors (the 'sorting-mechanism' view). However, the conclusion is still not clear. For example, Dee (2004) exploits the adoption of child labor laws in the U.S within the Instrumental Variable framework to conclude that education promotes voter participation and support for free speech. Milligan et al. (2004) uses school leaving age acts in the U.S and U.K as instrumental variables and find that educational attainment is linked to political interest and involvement. They also find a strong relationship between education and voting for the U.S, but not for the U.K. Exploiting various interventions such as preschool activities, extra mentoring, and smaller classes that can affect educational attainment, Sondheimer and Green (2010) provide a strong association between education and voter turnout. Also studying the context of the U.S, Mayer (2011) employs genetic matching to provide consistent evidence that educational attainment increases political participation index composed of eight participatory acts.

On the other hand, there are also a number of studies that show support for the 'sortingmechanism' view. For example, Kam and Palmer (2008) employ the propensity score matching method to find no statistical relationship between educational attainment and political participation in the U.S. Relying on a reform in the Norwegian educational systems as an exogenous source of variation, Pelkonen (2012) documents that additional education has no impact on voter turnout and several measures of civic outcomes. Exploiting the exogenous rise in education levels induced by the Vietnam-era draft, Berinsky and Lenz (2011) report no evidence that education increases voter turnout among American males. Also focusing on the U.S, Highton (2009) exploits panel data that can account for individual-specific characteristics 
and shows that there is no significant effect of education on political awareness.

Our study brings the following contributions to this ongoing debate. First, we contribute to the unresolved debate on the causal link between education and political engagement by exploiting the plausibly exogenous variation in education induced by the compulsory schooling reforms to identify the relationship of interest. Second, the paper complements prior works by rigorously examine various dimensions of political engagement, including political interest, knowledge, attitude, voting, and affiliation. Third, the wide coverage of 39 countries in our sample reduce the threats to external validity of our estimates, making the analysis meaningful to policymakers from many governments.

\section{Data}

In this study, we employ the International Social Survey Programme (ISSP) which is a cross-national collaboration project where data are collected by individual member countries. The data are then integrated into an international data file and distributed by the GESIS Data Archive for the Social Sciences (Leibniz Institute for the Social Sciences). The ISSP's surveys cover a wide range of topics relevant to social research including citizenship, environment, gender roles, government, etc. For the purpose of our analysis, we employ five waves of the Role of Government module (1985, 1990, 1996, 2006, and 2016) where respondents from each country are asked about their political opinions, attitudes, and behaviors (ISSP-RG). Besides political outcomes, demographic characteristics such as age, gender, marital status, etc. are also available in the module.

Drawing from the ISSP-RG, we consider three groups of political outcomes, including (i) degree of interest in and knowledge of politics, (ii) attitudes towards political freedoms, and (iii) participatory acts. To reflect individuals' political interest and knowledge, we construct two variables, Interest in Politics and Knowledge of Politics. These variables are based on respondents' answers to the question about their degree of interest in politics and the self-assessed understanding of important political issues. The responses are placed into a five-point scale with 1 representing the strongest (very) and 5 representing the weakest indicators $($ not at all). We then compute the variables Interest in Politics and Knowledge of 
Politics as zero-one indicators taking the value of one if the response was coded 1 or 2 , and zero otherwise.

To capture attitudes towards political freedoms, we construct four variables, Protesters' Public Meetings, Protesters' Demonstrations, Revolutionists' Public Meetings, and Revolutionists' Book Publications. These variables are based on respondents' perceptions of people/organizations running protests and revolutions. Specifically, in terms of protests, respondents were asked whether protesters should be allowed to: (i) organize public meetings, and (ii) organize marches and demonstrations. Regarding revolutions, respondents were asked whether revolutionists should be allowed to: (i) organize public meetings, and (ii) publish books. Responses are codified into a four-point scale ranging from 1-definitely to 4-definitely not. Our variables are indicators coded as 1 if the response takes the values of 1 or 2 , and zero otherwise.

In the third group, participatory acts consist of voting behavior and political affiliation. Voting behavior is measured by an indicator (Vote) that takes the value of one if the respondent voted in the last general election and zero otherwise. Political affiliation is proxied by five zero-one variables, Far-left, Center-left, Center, Right, Far-right. These are indicators for the position in the left-right scale of the party for which the respondent voted. In the political spectrum, the left-wing politics (including the far-left and the center-left) endorses freedom, equality, fraternity, rights, progress, reform, and internationalism while the right-wing politics (including the center-right and the far-right) emphasizes authority, hierarchy, order, duty, tradition, reaction and nationalism (Heywood, 2015). Center (or centrism) refers to a political position in the middle between the left wing and the right wing. Five political affiliation categories are based on the party the respondent voted for and expert judgments from the country-specific parties to convert into the left-right scale (GESIS, 2018).

\section{Empirical Methodology}




\subsection{Ordinary Least Square Method}

To investigate the relationship between the education and political engagement, we begin with the Ordinary Least Square (OLS) method by estimating the following equation,

$$
Y_{i y c t}=\alpha_{0}+\alpha_{1} \text { Education }_{\text {iyct }}+X_{\text {iyct }}^{\prime} \Omega+\lambda_{c}+\delta_{t}+\mu_{c y}+\epsilon_{i y c t}
$$

where the subscripts $i, y, c$, and $t$ refer to individual, year of birth, country, and survey year, respectively. The dependent variable $Y_{\text {iyct }}$ stands for perceptions on one's interest in politics (Interest in Politics), understandings of politics (Knowledge of Politics), various measures of attitude towards political freedoms (Protesters' Public Meetings, Protesters' Demonstrations, Revolutionists' Public Meetings, and Revolutionists' Book Publications), and

political participatory acts (Vote, Far-left, Center-left, Center, Center-right, and Far-right). Our main explanatory variable, Education iyct $_{\text {, }}$ represents the number of educational years completed by the individual. The vector $X_{\text {iyct }}^{\prime}$ includes other covariates capturing individuals' characteristics such as household size, place of living, occupation sector, gender, marital status, and birth year fixed effects. In addition, the terms $\lambda_{c}, \delta_{t}$, and $\mu_{c y}$ stand for country fixed effects, survey year fixed effects, and country-specific birth cohort trend. Finally, we denote by $\epsilon_{i y c t}$ the error term. Standard errors throughout the paper are clustered at the country-by-birth year level.

Unfortunately, estimating equation (1) via the OLS method can bias the coefficient of interest $\alpha_{1}$ because there exist unobserved factors jointly determine both educational attainment and political outcomes. For example, children born to parents with high socioeconomic status who are politically engaged and politically knowledgeable might end up staying longer in school. Such parents could possibly impart political values to their children, encourage education, and make sure their children attend high-quality schools. In other words, the unobserved family traits may simultaneously influence both educational attainment and political attitudes-behaviors, confounding the causal relationship of interest. Therefore, we proceed to discuss how we address such endogeneity issues in the next section. 


\subsection{Instrumental Variable Method Using Compulsory Education Reforms}

To overcome the confounding possibilities that the OLS could not address, we employ the Instrumental Variable (IV) method to estimate the impact of education on political engagement. Specifically, we exploit the changes in the number of educational years induced by the compulsory education reforms as the source of exogenous variation. The compulsory education reforms raise the mandatory years of education by one or more years for cohorts born after a given year while those who just missed the age cut-off of the law are not affected. As a result, individuals born two or three years apart are subject to different levels of compulsory schooling, which ultimately affects their educational attainment.

Within the IV framework, an individual's educational attainment is instrumented by his/her exposure to the compulsory education reform. The IV approach can tease out the causal effects of education on political engagement from the extension of the length of schooling for would-be-dropout individuals. As a result, the differences in political outcomes can be attributed to the differences in educational attainment. Empirically, we implement the IV method in a two-stage procedure. The first-stage regression is given by,

$$
\text { Education }_{\text {iyct }}=\gamma_{0}+\gamma_{1} \text { Reform }_{y c}+X_{i y c t}^{\prime} \Omega+\lambda_{c}+\delta_{t}+\mu_{c y}+\epsilon_{i y c t}
$$

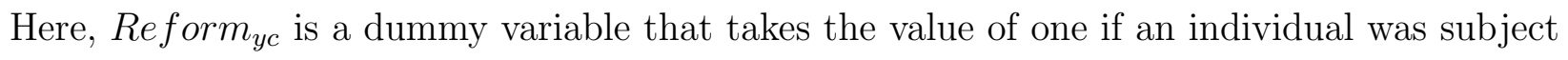
to the compulsory education reform in his/her country, and zero otherwise. Exposure is determined by the individual's birth year and the reform year in his/her country. Other notations remain the same. If the compulsory education reforms indeed increase the educational attainment of affected individuals, we expect $\gamma_{1}$ to be positive and statistically significant.

To have clear identification with the IV approach, we place several restrictions on our sample. First, we limit our sample to individuals aged 26 and above to isolate the impacts of complete education, assuming that educational attainment remained unchanged after the age of 25 . Second, we exclude individuals who were right at the age cut-off when the reforms took effect (focal cohort) because it is unclear whether these individuals were exposed to the reforms or not. Then, we only consider individuals born up to five years before and after the focal 
cohorts. In particular, the treatment group (i.e. those exposed to the reform) consists of individuals born up to five years after the focal cohort. Individuals born up to five years before the focal cohort constitute the control group as they are unaffected by the reforms. The breadth of this five-year window is intended to exclude the occurrence of other potential societal changes which could confound the effects of interest. At the same time, the window is wide enough to ensure the sample size for an adequate power of estimation.

For example, let us consider the reform in Belgium which extended the length of mandatory schooling from 8 to 12 years. The reform was implemented in 1983 requiring individuals in the eighth grade at the time to finish 12 years of schooling. As the school starting age in Belgium was six, the focal cohort consists of those born in 1969 (equal to $1983-8-6$ ). It is unclear whether this cohort was exposed to the reform because individuals born in the first few months of the year might have finished the eighth grade before the reform became effective, while those born in the last few months were still attending the eighth grade and affected by the reform. Therefore, we drop the focal cohort of 1969. The sample, thus, comprises the cohorts of 1964-1968 serving as the control group (unexposed to the reform) and the cohorts of 1970-1974 serving as the treatment group (exposed to the reform).

Information on the compulsory education reforms for all countries in our ISSP-RG sample was collected from their official legislation. The name of the legislation, the year of enactment, and a brief summary are described in Table A1 in the appendix. In general, each country has its own law except for the following groups of countries sharing the same laws: (i) Czech and Slovakia which were part of Czechoslovakia, (ii) Croatia and Slovenia which were part of Yugoslavia, (iii) Georgia, Latvia, Lithuania, and Russia which were part of the Soviet Union, and (iv) England, Wales, and Scotland which are part of the United Kingdom. Descriptive statistics of the variables used in this study are presented in Table A2 in the appendix.

After the first stage in equation (2), we get the predicted value Ed $\widehat{\text { ucation }}_{\text {iyct }}$ and proceed to the second stage as follows,

$$
Y_{\text {iyct }}=\beta_{0}+\beta_{1} \text { Education }_{\text {iyct }}+X_{\text {iyct }}^{\prime} \Omega+\lambda_{c}+\delta_{t}+\mu_{c y}+\epsilon_{\text {iyct }}
$$


Our main explanatory variable is the predicted value of education Ed $\widehat{\text { cation }}_{\text {iyct }}$ obtained from equation (2). The coefficient of interest is $\beta_{1}$ which captures the effects of education on political outcomes. For the sake of completeness, the reduced-form regression is given by,

$$
Y_{\text {iyct }}=\theta_{0}+\theta_{1} \text { Reform }_{y c}+X_{i y c t}^{\prime} \Omega+\lambda_{c}+\delta_{t}+\mu_{c y}+\epsilon_{i y c t}
$$

where $\theta_{1}$ summarizes the effects of exposure to compulsory education reforms on political outcomes. For the coefficient of interest $\beta_{1}$ to have the causal interpretation, two conditions need to be satisfied, including: (i) a strong first stage and (ii) an exclusion restriction.

The first condition refers to the strong correlation between the instrument $\left(\right.$ Reform $\left._{y c}\right)$ and the endogenous variable (Education iyct $_{\text {) }}$, conditioning on the remaining covariates. This condition can be examined by looking at the coefficient $\gamma_{1}$ in equation (2). We provide a preliminary visual illustration in Figure 1. The horizontal axis gives the distance between individual birth year and the birth year of the focal cohort (0 corresponds to the focal cohort). To facilitate the illustration, we recenter the cohorts because reforms were implemented in different years across countries. The vertical axis presents the average years of education of each cohort scaled by the country's mean educational years. We scale the average education because the nature of the reforms (e.g. timing, the duration of mandatory schooling, ...) differs across countries. In any case, we report the non-scaled version in Figure A1 in the appendix. Visually, Figure 1 depicts a sharp jump in the number of educational years for the cohorts subject to the compulsory education reforms. Reported in Column 1 of Table 1, the first-stage coefficient, $\gamma_{1}$, is both statistically and economically significant. Exposure to the compulsory education reforms induces an individual to complete approximately 0.6 more years of education, pointing to a strong first stage. We further provide the first-stage F-statistic in each IV regression which will be discussed in greater detail in Section 4 .

The second condition, exclusion restriction, means exposure to the compulsory education reforms can only influence individuals' political engagement through the change in educational attainment. Although it is not possible to empirically test for this condition, the exclusion restriction is still feasible for multiple reasons. First, it is unlikely for the compulsory education 
reforms to be correlated with simultaneous societal changes that might affect individuals' political engagement. It is because we explore the perceptions and behaviors of individuals many years after their exposure to the education reforms. Second, there is little chance of the implementation of the reforms picking up underlying country-specific educational trends. For example, one may worry that the cost of stricter enforcement of the reforms might possibly be lower for countries expecting faster rises in high school graduation rates. However, as firmly established in the literature, such possibilities are unlikely since stricter enforcement raises educational attainment and not vice versa (Lochner and Moretti, 2004; Milligan et al., 2004).

Figure 1: Impacts of Compulsory Schooling Laws on Educational Attainment

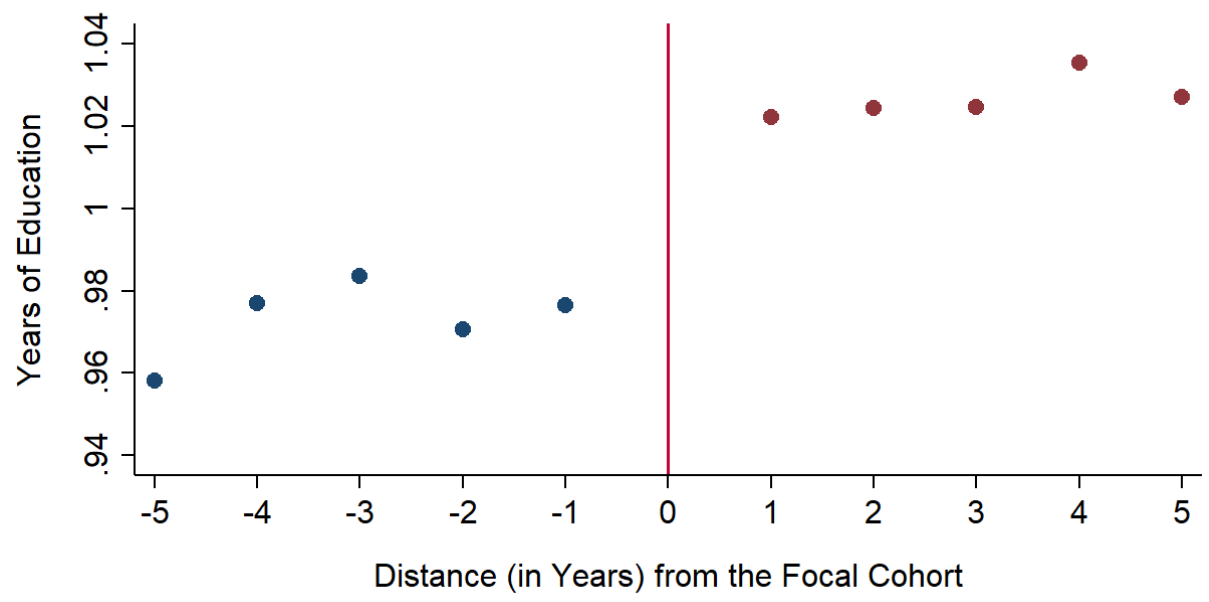

Note: The horizontal axis gives the distance between individual birth year and the birth year of the focal cohort. The vertical axis presents the average years of education of each cohort scaled by the country's mean educational years.

\section{Results}

\subsection{Interest in Politics and Knowledge of Politics}

The estimated impacts of education on individual self-perceived interest in and knowledge of politics are presented in Table 1 . Column 1 shows the first-stage coefficient. Columns 2 and 3 provide the OLS estimates. Columns 4 and 5 report the results from the IV models. Columns 6 and 7 display the reduced-form estimates. Each column is a separate regression and the column headings specify the dependent variables. 
We start with the OLS estimates of the relationships in Columns 2 and 3. Education is positively associated with the level of political interest and knowledge of the individual. Specifically, an additional year of education makes the individual more interested in political affairs by 2.1 percentage points. The effect on the knowledge of politics is statistically significant with the same magnitude. However, as previously mentioned in Section 3, the OLS estimations fail to take into account unobserved factors jointly determining educational attainment and perceptions on the degree of interest and understanding of politics. The apparent positive estimated effect of education produced by the OLS model may reflect the spurious influence of other individual traits such as family socioeconomic status and personal ability. To account for such confounding factors, we need to adopt the IV model which exploits the plausibly exogenous changes in educational attainment.

Table 1: Interest in Politics and Knowledge of Politics

\begin{tabular}{|c|c|c|c|c|c|c|c|}
\hline & \multirow{2}{*}{$\begin{array}{c}\text { First Stage } \\
\text { Years of } \\
\text { Education }\end{array}$} & \multicolumn{2}{|c|}{ OLS } & \multicolumn{2}{|c|}{ IV-Second Stage } & \multicolumn{2}{|c|}{ Reduced Form } \\
\hline & & $\begin{array}{c}\text { Interest } \\
\text { in Politics }\end{array}$ & $\begin{array}{l}\text { Knowledge } \\
\text { of Politics }\end{array}$ & $\begin{array}{c}\text { Interest } \\
\text { in Politics }\end{array}$ & $\begin{array}{l}\text { Knowledge } \\
\text { of Politics }\end{array}$ & $\begin{array}{c}\text { Interest } \\
\text { in Politics }\end{array}$ & $\begin{array}{l}\text { Knowledge } \\
\text { of Politics }\end{array}$ \\
\hline & (1) & $(2)$ & (3) & (4) & $(5)$ & $(6)$ & $(7)$ \\
\hline Years of Education & & $\begin{array}{c}0.021^{* * *} \\
(0.001)\end{array}$ & $\begin{array}{c}0.021^{* * *} \\
(0.001)\end{array}$ & $\begin{array}{c}0.067^{* * *} \\
(0.022)\end{array}$ & $\begin{array}{c}0.085^{* * *} \\
(0.032)\end{array}$ & & \\
\hline Reform & $\begin{array}{c}0.598^{* * *} \\
(0.107)\end{array}$ & & & & & $\begin{array}{c}0.044^{* * *} \\
(0.014)\end{array}$ & $\begin{array}{c}0.055^{* * *} \\
(0.018)\end{array}$ \\
\hline F-Statistic & & & & 37.40 & 27.71 & & \\
\hline Observations & 17,429 & 16,470 & 14,484 & 16,470 & 14,484 & 16,470 & 14,484 \\
\hline
\end{tabular}

Note: ${ }^{*} p<0.1,{ }^{* *} p<0.05,{ }^{* * *} p<0.01$. All regressions control for household size, place of living, occupation sector, gender, marital status, and birth year fixed effects, country fixed effects, survey year fixed effects, and country-specific birth cohort trend. Robust standard errors are clustered at the country-by-birth year level.

We proceed to the IV regressions in Columns 4 and 5. We still find positive and statistically significant impacts of education on the extent to which the individual is interested in politics and has a good understanding of politics. An additional year of education raises the individual's interest in politics by 6.7 percentage points and increases the individual's self-perceived knowledge of politics by 8.5 percentage points. These effects represent the $21.3 \%$ and $18 \%$ increases relative to the control means in Table A2. The Kleibergen-Paap rk Wald F statistics (37.40 and 27.71) exceed the critical value thresholds, rejecting the 
hypothesis that the instrument is weak. ${ }^{4}$ In other words, the high values of the F-statistics further suggest that our IV models satisfy the strong first stage condition.

The reduced-form estimates are presented in Columns 6 and 7. Exposure to the compulsory education reforms is associated with a higher interest in politics by 4.4 percentage points. Exposed individuals also have better knowledge of politics by 5.5 percentage points. These estimates are both statistically and economically significant, representing the $14 \%$ and $11.7 \%$ increases compared to the mean values of the control group.

\subsection{Attitudes towards Political Freedoms}

The estimated impacts of educational attainment on attitudes towards political freedoms are reported in Table 2. Columns 1 and 2 provide the OLS estimates. Columns 3 and 4 present the results from the IV models. Columns 5 and 6 display the reduced-form estimates. We look at individuals' perceptions about protests and revolutions in Panel A and B, respectively. In each panel, each column is a separate regression and the column headings specify the dependent variables.

Evident from Columns 1 and 2, better educated individuals tend to support political freedoms. The OLS estimates are all positive and statistically significant. Specifically, completing one more year of education makes the individual 0.8 and 1.0 percentage points more likely to think that the organization of public meetings and marches-demonstrations to protest against the government should be allowed, respectively (Panel A). One year increase in educational attainment is also associated with 0.8 and 1.2 percentage points higher probability of the individual thinking that revolutionists should be allowed to hold public meetings and publish books to express their views, respectively (Panel B). Again, the strong correlations produced by the OLS models might just reflect the confounding influence of unobserved characteristics jointly determining an individual's education and attitudes towards political freedoms.

Overcoming those shortcomings by comparing individuals whose educational differences are induced by their exposure to the exogenous reforms, the IV estimates in Columns 3 and 4 point

\footnotetext{
4 The Stock-Yogo weak ID test critical values are 16.38, 8.96, 6.66 at the $10 \%, 15 \%$, and $20 \%$ maximal IV size, respectively.
} 
to the same direction as the OLS ones. Regarding the attitude towards protests, an additional year of education raises the probability that the individual approves of the organization of public meetings and marches-demonstrations to protest against the government by 6.0 and 8.0 percentage points, respectively (Panel A). Looking at the mean values of the control group in Table A2, these estimated impacts imply the average increases by $7.1 \%$ and $10.4 \%$. As for the attitude towards revolutions, completing one more year of education makes the individual 10.4 and 6.2 percentage points more likely to support revolutionists' organization of public meetings and book publication to express their views (Panel B). These estimates indicate the $20.3 \%$ and $10 \%$ increases in the proportions of individuals supporting revolutionary actions.

Table 2: Attitudes towards Political Freedoms

\begin{tabular}{|c|c|c|c|c|c|c|}
\hline & \multicolumn{2}{|c|}{ OLS } & \multicolumn{2}{|c|}{ IV-Second Stage } & \multicolumn{2}{|c|}{ Reduced Form } \\
\hline & $(1)$ & $(2)$ & $(3)$ & $(4)$ & $(5)$ & $(6)$ \\
\hline \multicolumn{7}{|c|}{ Panel A: Attitude towards Protests } \\
\hline & $\begin{array}{c}\text { Protesters' } \\
\text { Public } \\
\text { Meetings }\end{array}$ & $\begin{array}{l}\text { Protesters' } \\
\text { Demonstr- } \\
\text { ation }\end{array}$ & $\begin{array}{c}\text { Protesters' } \\
\text { Public } \\
\text { Meetings }\end{array}$ & $\begin{array}{l}\text { Protesters' } \\
\text { Demonstr- } \\
\text { ation }\end{array}$ & $\begin{array}{c}\text { Protesters' } \\
\text { Public } \\
\text { Meetings }\end{array}$ & $\begin{array}{l}\text { Protesters' } \\
\text { Demonstr- } \\
\text { ation }\end{array}$ \\
\hline Years of Education & $\begin{array}{c}0.008^{* * *} \\
(0.001)\end{array}$ & $\begin{array}{c}0.010^{* * *} \\
(0.001)\end{array}$ & $\begin{array}{c}0.060^{* *} \\
(0.024)\end{array}$ & $\begin{array}{c}0.080^{* *} \\
(0.032)\end{array}$ & & \\
\hline Reform & & & & & $\begin{array}{c}0.038^{* * *} \\
(0.014)\end{array}$ & $\begin{array}{c}0.046^{* * *} \\
(0.016)\end{array}$ \\
\hline $\begin{array}{l}\text { F-Statistic } \\
\text { Observations }\end{array}$ & 16,308 & 16,220 & $\begin{array}{c}31.24 \\
16,308\end{array}$ & $\begin{array}{c}25.90 \\
16,220\end{array}$ & 16,308 & 16,220 \\
\hline \multicolumn{7}{|c|}{ Panel B: Attitude towards Revolutions } \\
\hline & $\begin{array}{l}\text { Revolution- } \\
\text { ists' Public } \\
\text { Meetings }\end{array}$ & $\begin{array}{l}\text { Revolution- } \\
\text { ists' Book } \\
\text { Publications }\end{array}$ & $\begin{array}{l}\text { Revolution- } \\
\text { ists' Public } \\
\text { Meetings }\end{array}$ & $\begin{array}{l}\text { Revolution- } \\
\text { ists' Book } \\
\text { Publications }\end{array}$ & $\begin{array}{l}\text { Revolution- } \\
\text { ists' Public } \\
\text { Meetings }\end{array}$ & $\begin{array}{l}\text { Revolution- } \\
\text { ists' Book } \\
\text { Publications }\end{array}$ \\
\hline Years of Education & $\begin{array}{c}0.008^{* * *} \\
(0.001)\end{array}$ & $\begin{array}{c}0.012^{* * *} \\
(0.001)\end{array}$ & $\begin{array}{c}0.104^{* * *} \\
(0.037)\end{array}$ & $\begin{array}{l}0.062^{*} \\
(0.033)\end{array}$ & & \\
\hline Reform & & & & & $\begin{array}{c}0.059^{* * *} \\
(0.018)\end{array}$ & $\begin{array}{l}0.034^{* *} \\
(0.017)\end{array}$ \\
\hline F-Statistic & & & 23.67 & 21.74 & & \\
\hline Observations & 15,866 & 15,624 & 15,866 & 15,624 & 15,866 & 15,624 \\
\hline
\end{tabular}

Note: ${ }^{*} p<0.1,{ }^{* *} p<0.05,{ }^{* * *} p<0.01$. All regressions control for household size, place of living, occupation sector, gender, marital status, and birth year fixed effects, country fixed effects, survey year fixed effects, and country-specific birth cohort trend. Robust standard errors are clustered at the country-by-birth year level.

In both panels, the large first-stage F-statistics suggest that exposure to the compulsory education reforms is a strong instrument for individual educational attainment. Collectively, the results lend evidence for the positive relationship between education and support for 
political freedoms.

Finally, the reduced-formed estimates presented in Columns 5 and 6 suggest that exposure to the compulsory education reform indeed makes the individual more likely to endorse political freedoms. Individuals affected by the reforms tend to approve of the use of public meetings and demonstrations-marches as the ways to protest against the government. Such individuals are also inclined to think that the organization of public meetings and the publications of books by revolutionary parties should be allowed.

\subsection{Participatory Acts}

Thus far, we have provided evidence that education is positively associated with individual interest in and knowledge of politics as well as supportive attitudes towards political freedoms. Now, we proceed to explore whether the effects of educational attainment can translate into changes in participatory acts. We present the estimated impacts of educational attainment on voting behavior and political affiliation in Table 3. Columns 1 and 2 provide the OLS estimates. Columns 3 and 4 present the results from the IV models. Columns 5 and 6 display the reduced-form estimates. We look at individuals' voting behavior in Panel A. Individuals' affiliation with the left wing, center, and the right wing are examined in Panel B, C, and D, respectively. In each panel, each column is a separate regression and the column headings indicate the dependent variables.

Voting - The OLS model produces a positive and significant estimate for the correlation between educational attainment and voting behavior (Panel A, Column 1). Specifically, an additional year of education raises the probability of the individual voting in the general election by 0.7 percentage points. Nevertheless, employing the IV method, we find that the coefficient carries the opposite sign and becomes statistically indistinguishable from zero (Panel A, Column 3). Although we have the strong first stage evident by a high value of the F-statistic, there is no effect of educational attainment on voting once the confounding unobserved determinants of schooling and voting are accounted for. Unsurprisingly, the reduced-form estimate is negative and statistically insignificant. 
Table 3: Impacts of Education on Political Behaviors

\begin{tabular}{|c|c|c|c|c|c|c|}
\hline & \multicolumn{2}{|c|}{ OLS } & \multicolumn{2}{|c|}{ IV-Second Stage } & \multicolumn{2}{|c|}{ Reduced Form } \\
\hline & $(1)$ & $(2)$ & (3) & (4) & (5) & (6) \\
\hline \multicolumn{7}{|c|}{ Panel A: Political Participation } \\
\hline & Vote & & Vote & & Vote & \\
\hline Years of Education & $\begin{array}{c}0.007^{* * *} \\
(0.001)\end{array}$ & & $\begin{array}{l}-0.017 \\
(0.022)\end{array}$ & & & \\
\hline Reform & & & & & $\begin{array}{l}-0.012 \\
(0.016)\end{array}$ & \\
\hline F-Statistic & & & 22.33 & & & \\
\hline Observations & 10,416 & & 10,416 & & 10,416 & \\
\hline \multicolumn{7}{|c|}{ Panel B: Left-wing Affiliation } \\
\hline & Far-left & Center-left & Far-left & Center-left & Far-left & Center-left \\
\hline Years of Education & $\begin{array}{l}-0.001 \\
(0.001)\end{array}$ & $\begin{array}{c}0.000 \\
(0.001)\end{array}$ & $\begin{array}{l}-0.004 \\
(0.016)\end{array}$ & $\begin{array}{c}0.004 \\
(0.032)\end{array}$ & & \\
\hline Reform & & & & & $\begin{array}{l}-0.002 \\
(0.009)\end{array}$ & $\begin{array}{c}0.002 \\
(0.018)\end{array}$ \\
\hline F-Statistic & & & 17.59 & 17.59 & & \\
\hline Observations & 12,038 & 12,038 & 12,038 & 12,038 & 12,038 & 12,038 \\
\hline \multicolumn{7}{|c|}{ Panel C: Center Affiliation } \\
\hline & Center & & Center & & Center & \\
\hline Years of Education & $\begin{array}{c}0.004^{* * *} \\
(0.001)\end{array}$ & & $\begin{array}{l}-0.011 \\
(0.028)\end{array}$ & & & \\
\hline Reform & & & & & $\begin{array}{l}-0.006 \\
(0.016)\end{array}$ & \\
\hline F-Statistic & & & 17.59 & & & \\
\hline Observations & 12,038 & & 12,038 & & 12,038 & \\
\hline \multicolumn{7}{|c|}{ Panel D: Right-wing Affiliation } \\
\hline & Center-right & Far-right & Center-right & Far-right & Center-right & Far-right \\
\hline Years of Education & $\begin{array}{l}0.002^{*} \\
(0.001)\end{array}$ & $\begin{array}{c}-0.001^{* *} \\
(0.001)\end{array}$ & $\begin{array}{c}0.003 \\
(0.029)\end{array}$ & $\begin{array}{c}0.011 \\
(0.011)\end{array}$ & & \\
\hline Reform & & & & & $\begin{array}{c}0.002 \\
(0.016)\end{array}$ & $\begin{array}{c}0.006 \\
(0.006)\end{array}$ \\
\hline F-Statistic & & & 17.59 & 17.59 & & \\
\hline Observations & 12,038 & 12,038 & 12,038 & 12,038 & 12,038 & 12,038 \\
\hline
\end{tabular}

Note: ${ }^{*} p<0.1,{ }^{* *} p<0.05,{ }^{* * *} p<0.01$. All regressions control for household size, place of living, occupation sector, gender, marital status, and birth year fixed effects, country fixed effects, survey year fixed effects, and country-specific birth cohort trend. Robust standard errors are clustered at the country-by-birth year level.

Political Affiliation - According to the OLS models, the better educated individual is more likely to take the center and center-right positions as well as less likely to adopt the far-right position in the left-right political spectrum (Panel C, Column 1 and Panel D, Columns 1-2). Despite the statistical significance, the magnitudes of the effects are very small. The remaining OLS coefficients are both statistically and economically indistinguishable from zero. 
As discussed in Section 3, the OLS models only provide biased estimates for the effects of education on political affiliation. It is because unobserved individual and family traits which jointly determine both educational attainment and political outcomes are not controlled for within the OLS framework.

Therefore, to account for the endogeneity of education, we employ the IV models which hinge upon the plausibly exogenous variation in educational attainment induced by the compulsory schooling reforms. The IV estimates in Columns 3 and 4 are all statistically and economically insignificant, suggesting that education seems to not affect individuals' political affiliation. In other words, the better educated are no more likely to adopt any specific position in the left-right political spectrum. Despite the strong first stage evidenced by large F-statistics, all reduced-form estimates are small in magnitude and fall short of conventional significance.

Taken together, although education exerts positive effects on political interest, political knowledge, and attitudes towards political freedoms, it does not alter participatory acts in politics. Specifically, more educated individuals are no more likely to participate in voting nor take the left-wing, center, or right-wing positions in the political spectrum.

\subsection{Discussions}

Collectively, we detect positive impacts of education on individual interest in politics, selfperceived political knowledge, and supportive attitudes towards political freedoms. In particular, an additional year of education raises the individual's interest in politics by 6.7 percentage points and increases the individual's self-perceived political knowledge by 8.5 percentage points. Better-educated individuals also tend to support political freedoms. Specifically, a one-year increase in education raises the probability that the individual endorses the organization of public meetings and marches-demonstrations to protest against the government by 6.0 and 8.0 percentage points, respectively. The individual is also 10.4 and 6.2 percentage points more likely to support revolutionists' organization of public meetings and book publication to express their views. Nevertheless, the political return to education does not extend to participatory acts. Particularly, the better educated are no more likely to vote in elections nor adopt any specific position in the left-right political spectrum. 
Regarding political interest, political knowledge, and attitudes towards political freedoms, our findings are consistent with studies supporting the 'cause' view of education. ${ }^{5}$ According to this group of studies, there are multiple explanations for the political return to education in terms of political knowledge, interest, and attitudes. Being regarded as human capital enhancing, education equips individuals with better cognitive ability that enables them to assimilate complicated political information and lowers the opportunity cost of acquiring such knowledge. Besides, individuals staying longer in school are more likely to be exposed to course contents that stimulate the interest in politics. As a result, better-educated individuals tend to possess a good understanding of politics and current affairs as well as a keen interest in such topics. Furthermore, by imparting values of civil liberties and human rights to students, education can shape individuals' perceptions towards political freedoms.

Regarding political participatory acts, our results lend support to the 'sorting-mechanism' view by showing that once the endogeneity of education is accounted for, better-educated individuals are no more likely to cast a vote in an election nor adopt any specific position in the left-right political spectrum. ${ }^{6}$ The non-existence of such effects could be explained by two factors. First, in many countries, prior to elections, eligible individuals need to do the voter registration which involves a lot of bureaucratic hurdles (Milligan et al., 2004). By raising the labor market return, education also increases the opportunity cost of time associated with voter registration, thus reducing the probability of participation. Second, it is possible that better-educated individuals might consider voting just an expressive act where one single vote is unlikely to change the outcome of an election; therefore, they are no more likely to vote (Campbell, 2006). These two forces could have counteracted the positive effects of education on political awareness, political interest, and supportive attitudes towards political freedoms, thus leaving participatory acts unchanged.

Taken together, our study provides some evidence for the political return associated with education. Despite the non-existent impact on participatory acts, education does cultivate

5 Wolfinger and Rosenstone (1980), Rosenstone and Hansen (1993), Niemi and Junn (1998), Torney-Purta et al. (1999), Galston (2001), Dee (2004), Milligan et al. (2004), Sondheimer and Green (2010), Mayer (2011)

${ }^{6}$ Luskin (1990), Nie et al. (1996), Herrnstein and Murray (1994), Kam and Palmer (2008), Highton (2009), Berinsky and Lenz (2011), Pelkonen (2012), Persson (2013) 
political interest, promote the acquisition of political knowledge, and foster supportive attitudes towards political freedoms. To put it differently, education may not lead to broader participation among the citizenry but instead improve the quality of political participation, given that politically interested and knowledgeable individuals are the more effective participants in a representative democracy (Lassen, 2005). Therefore, our study further justifies government interventions in the provision and financing of education.

\section{Conclusions}

The study contributes to the literature by examining the extent to which educational attainment influences political engagement of individuals. To empirically conduct the analysis, we employ the Role of Government module of the International Social Survey Programme data. To account for the endogeneity of education, we adopt the Instrumental Variable (IV) model by exploiting the plausibly exogenous changes in educational years induced by the compulsory education reforms. The reforms raise the mandatory years of education by one or more years for cohorts born after a given year while those who just missed the age cut-off of the law are not affected. Therefore, individuals may attain different levels of schooling just because they were born a few years apart thus subject to different lengths of mandatory education. In other words, the IV approach can tease out the causal effects of education on political engagement from the extension of the length of schooling for would-be-dropout individuals.

Our study reaches the following findings. First, educational attainment is positively associated with individual interest in politics and self-perceived knowledge of politics. Specifically, completing one more year of education raises the individual's interest in politics by 6.7 percentage points and increases the individual's self-perceived knowledge of politics by 8.5 percentage points. Second, better education individuals are more inclined to possess supportive attitudes towards political freedoms. An additional year of education raises the probability of the individual endorsing the organization of public meetings and marches-demonstrations to protest against the government by 6.0 and 8.0 percentage points, respectively. The individual is also 10.4 and 6.2 percentage points more likely to support revolutionists' organization of public meetings and publication of books to express their views. Finally, the political return 
to education does not extend to participatory acts in politics. There is little evidence that education influences voting nor political affiliation.

Despite the absence of effects on participatory acts by fostering political interest and knowledge, the role of education may not lie with broadening participation among the citizenry but lie with enhancing the quality of political participation. To an extent that a fully informed electorate can improve the quality of democracy, our findings support the Pigouvian subsidies for education to reach a more socially efficient acquisition of education. 


\section{References}

[1] Achen, C. H. (2002). Parental socialization and rational party identification. Political Behavior, 24(2), 151-170.

[2] Andolina, M. W., Jenkins, K., Zukin, C., \& Keeter, S. (2003). Habits from home, lessons from school: Influences on youth civic engagement. PS: Political Science and Politics, $36(2), 275-280$.

[3] Barrett, M., \& Brunton-Smith, I. (2014). Political and civic engagement and participation: Towards an integrative perspective. Journal of Civil Society, 10(1), 5-28.

[4] Berinsky, A. J., \& Lenz, G. S. (2011). Education and political participation: Exploring the causal link. Political Behavior, 33(3), 357-373.

[5] Brady, H. E. (1999). Political participation. Measures of political attitudes, 2, 737-801.

[6] Campbell, D. E. (2006). Why we vote: How schools and communities shape our civic life (Vol. 87). Princeton University Press.

[7] Dahl, R. A. (1973). Polyarchy: Participation and opposition. Yale University Press.

[8] Dee, T. S. (2004). Are there civic returns to education?. Journal of Public Economics, 88(9-10), 1697-1720.

[9] Friedman, M. (1962). Capitalism and freedom. University of Chicago Press.

[10] Galston, William A. (2001). Political knowledge, political engagement and civic education. Annual Review of Political Science

[11] GESIS. (2018). ISSP 2016 Role of Government V, Variable Report: Documentation release 2018/09/19, related to the international dataset Archive-Study-No. ZA6900 Version 2.0.0. Variable Reports 2018 - 09. Cologne: GESIS.

[12] Herrnstein, Richard J., and Murray, Charles (1994). The Bell Curve: Intelligence and Class Structure in American Life. New York: The Free Press.

[13] Heywood, A. (2015). Key concepts in politics and international relations. Macmillan International Higher Education.

[14] Highton, B. (2009). Revisiting the relationship between educational attainment and political sophistication. The Journal of Politics, 71(4), 1564-1576.

[15] Kam, C. D., \& Palmer, C. L. (2008). Reconsidering the effects of education on political participation. The Journal of Politics, $70(3)$, 612-631.

[16] Lassen, D. D. (2005). The effect of information on voter turnout: Evidence from a natural experiment. American Journal of Political Science, 49(1), 103-118. 
[17] Le, K., \& Nguyen, M. (2020). Shedding light on maternal education and child health in developing countries. World Development, 133, 105005.

[18] Lochner, L., \& Moretti, E. (2004). The effect of education on crime: Evidence from prison inmates, arrests, and self-reports. American Economic Review, 94 (1), 155-189.

[19] Luskin, Robert C. (1990). Explaining political sophistication. Political Behavior, 12(4): $331-355$.

[20] Mayer, A. K. (2011). Does education increase political participation?. The Journal of Politics, $73(3), 633-645$.

[21] Milligan, K., Moretti, E., \& Oreopoulos, P. (2004). Does education improve citizenship? Evidence from the United States and the United Kingdom. Journal of Public Economics, 88(9-10), 1667-1695.

[22] Nie, Norman H., Junn, Jane, and Stehlik-Berry, Kenneth (1996). Education and Democratic Citizenship in America. Chicago: University of Chicago Press.

[23] Niemi, Richard, and Junn, Jane (1998). Civic Education: What Makes Students Learn. New Haven: Yale University Press.

[24] Pekkarinen, T. (2008). Gender differences in educational attainment: Evidence on the role of tracking from a Finnish quasi-experiment. Scandinavian Journal of Economics, $110(4), 807-825$.

[25] Pelkonen, P. (2012). Length of compulsory education and voter turnout - evidence from a staged reform. Public Choice, 150(1-2), 51-75.

[26] Persson, M. (2014). Testing the relationship between education and political participation using the 1970 British cohort study. Political Behavior, 36(4), 877-897.

[27] Putnam, R. D. (1995). Tuning in, tuning out: The strange disappearance of social capital in America. PS: Political Science 8 Politics, $28(4), 664-683$.

[28] Rosenstone, Steven, and Hansen, John Mark (1993). Mobilization, Participation, and Democracy in America. New York: Macmillan.

[29] Silles, M. A. (2009). The causal effect of education on health: Evidence from the United Kingdom. Economics of Education review, 28(1), 122-128.

[30] Smith, A. (1776). 1986, The Wealth of Nations. The Essential Adam Smith (WW Norton \& Company, New York).

[31] Sondheimer, R. M., \& Green, D. P. (2010). Using experiments to estimate the effects of education on voter turnout. American Journal of Political Science, 54(1), 174-189.

[32] Torney-Purta, J., Schwille, J., and Amadeo, J. (1999). Civic Education Across Countries: Twenty-Four National Case Studies from the IEA Civic Education Project. Amsterdam, The Netherlands: International Association for the Evaluation of Educational Achievement. 
[33] Verba, S., Schlozman, K. L., \& Brady, H. E. (1995). Voice and equality: Civic voluntarism in American politics. Harvard University Press.

[34] Westholm, A. (1999). The perceptual pathway: Tracing the mechanisms of political value transfer across generations. Political Psychology, 20(3), 525-551.

[35] Wolfinger, R. E., \& Rosenstone, S. J. (1980). Who votes?. Yale University Press.

[36] Zukin, C., Keeter, S., Andolina, M., Jenkins, K., \& Carpini, M. X. D. (2006). A new engagement?: Political participation, civic life, and the changing American citizen. Oxford University Press. 


\section{Appendix A}

Table A1: Compulsory Education Reforms by Country

\begin{tabular}{|c|c|c|}
\hline Country & Cohorts & Description \\
\hline \multirow{2}{*}{ AT } & C: $1947-1951$ & The duration of compulsory schooling in Austria was raised from 8 to 9 years by the \\
\hline & T: $1953-1957$ & $\begin{array}{l}\text { Federal law of July 25, 1962, on Compulsory Schooling. The reform was implemented } \\
\text { on September 1, 1966, affecting those in the eighth grade and younger at that time. } \\
\text { Since the school starting age in Austria was } 6 \text { at the time, we omit individuals born } \\
\text { in } 1952 \text { (i.e. 1966-8-6) because it was not clear whether this cohort was exposed to } \\
\text { the reform. }\end{array}$ \\
\hline \multirow[t]{2}{*}{$\mathrm{BE}$} & C: $1964-1968$ & According to the Law of June 29,1983 , on Compulsory Schooling, the length of \\
\hline & T: $1970-1974$ & $\begin{array}{l}\text { compulsory schooling in Belgium increased from } 8 \text { to } 12 \text { years. The reform became } \\
\text { effective in the same year affecting those in the eighth grade and below at that time. } \\
\text { Since Belgium's school starting age was } 6 \text { at the time, we exclude individuals born in } \\
1969 \text { (i.e. 1983-8-6). }\end{array}$ \\
\hline \multirow[t]{2}{*}{ BG } & C: $1941-1945$ & The Act on Closer Links between School and Life and on the Further Development of \\
\hline & $\mathrm{T}: 1947-1951$ & $\begin{array}{l}\text { Public Education (SG No.54/1959) extended the duration of Bulgaria's compulsory } \\
\text { schooling from } 7 \text { to } 8 \text { years. The reform required those in the seventh grade and } \\
\text { younger in } 1960 \text { to stay in school for } 8 \text { years. Since Bulgaria's school starting age was } \\
7 \text { at the time, we omit individuals born in } 1946 \text { (i.e. 1960-7-7). }\end{array}$ \\
\hline \multirow[t]{2}{*}{ CL } & C: $1949-1953$ & Prior to 1966, the primary education in Chile was mandatory and lasted for 6 years. In \\
\hline & $\mathrm{T}: 1955-1959$ & $\begin{array}{l}\text { 1966, Chile's government lengthened the duration of primary education (and shortened } \\
\text { the duration of secondary education) by } 2 \text { years, thus raising compulsory education } \\
\text { from } 6 \text { to } 8 \text { years. Since Chile's school starting age was } 6 \text { at the time, we drop those } \\
\text { born in } 1966 \text { (i.e. 1966-6-6). }\end{array}$ \\
\hline \multirow[t]{2}{*}{$\mathrm{CY}$} & C: $1969-1973$ & The Decision No. 25.942 of the Council of Ministers extended the duration of Cyprus's \\
\hline & $\mathrm{T}: 1975-1979$ & $\begin{array}{l}\text { compulsory schooling from } 6 \text { to } 9 \text { years. The reform was announced in } 1985 \text { and took } \\
\text { effect in 1986, thus affecting those in the sixth grade and younger in } 1986 \text {. Since } \\
\text { Cyprus's school starting age was } 6 \text { at the time, we omit individuals born in } 1974 \text { (i.e. } \\
\text { 1986-6-6). }\end{array}$ \\
\hline \multirow[t]{2}{*}{$\mathrm{DE}$} & C: $1927-1931$ & The Compulsory Schooling Act of the German Reich stipulated compulsory schooling \\
\hline & $\mathrm{T}: 1933-1937$ & $\begin{array}{l}\text { for } 8 \text { years to all children in Germany. The reform was implemented on July } 6,1938 \text {, } \\
\text { affecting all children with German citizenship. Since the school starting age was } 6 \text { at } \\
\text { the time, we exclude individuals born in } 1932 \text { (i.e. 1938-0-6). }\end{array}$ \\
\hline \multirow[t]{2}{*}{ DK } & C: $1953-1957$ & In Denmark, the duration of compulsory schooling was raised from 7 to 9 years by \\
\hline & $\mathrm{T}: 1959-1963$ & $\begin{array}{l}\text { the Amendment of the Public School Act (Law } 121 \text { of } 17 \text { June 1972). The reform } \\
\text { became effective in the same year affecting those in seventh grade and below at that } \\
\text { time. Since Denmark's school starting age was } 7 \text { at the time, we drop those born in } \\
1958 \text { (i.e. 1972-7-7). }\end{array}$ \\
\hline \multirow[t]{2}{*}{ ES } & C: $1953-1957$ & The duration of compulsory schooling in Spain was raised from 6 to 8 years by the \\
\hline & $\mathrm{T}: 1959-1963$ & $\begin{array}{l}\text { General Act on Education and Financing of Educational Reform (Law } 14 / 1970 \text { of } \\
\text { August } 4,1970 \text { ). The reform became effective in the same year affecting those in the } \\
\text { sixth grade and younger at that time. Since Spain's school starting age was } 6 \text { at the } \\
\text { time, we omit individuals born in } 1958 \text { (i.e. 1970-6-6). }\end{array}$ \\
\hline \multirow[t]{2}{*}{ FI } & C: $1956-1960$ & In 1968, The Act on Basic Education Reform $467 / 1968$ was introduced extending \\
\hline & $\mathrm{T}: 1962-1966$ & $\begin{array}{l}\text { the duration of Finland's compulsory schooling from } 6 \text { to } 9 \text { years. The reform was } \\
\text { gradually implemented by municipalities from } 1972 \text { through } 1977 \text {. However, according } \\
\text { to Pekkarinen (2008), the majority of the students across the country were affected by } \\
\text { the implementation in } 1974 \text {. Thus, we drop those born in } 1961 \text { (i.e. 1974-6-7), given } \\
\text { that the school starting age was } 7 \text { at the time. }\end{array}$ \\
\hline
\end{tabular}




\begin{tabular}{|c|c|c|}
\hline Country & Cohorts & Description \\
\hline FR & $\begin{array}{l}\text { C: } 1948-1952 \\
\text { T: } 1954-1958\end{array}$ & $\begin{array}{l}\text { According to the Berthoin Ordinance on Compulsory Education of January } 6,1959 \text {, } \\
\text { the length of compulsory schooling in France increased from } 8 \text { to } 10 \text { years. The reform } \\
\text { was implemented in } 1967 \text { affecting those in the eighth grade and younger at that time. } \\
\text { Since France's school starting age was } 6 \text { at the time, we drop individuals born in } 1953 \\
\text { (i.e. } 1967-8-6) \text {. }\end{array}$ \\
\hline $\mathrm{HU}$ & $\begin{array}{l}\text { C: } 1942-1946 \\
\text { T: } 1948-1952\end{array}$ & $\begin{array}{l}\text { The Law No. III of } 1961 \text { Concerning the Educational System of the Hungarian People's } \\
\text { Republic extended the duration of Hungary's compulsory schooling from } 8 \text { to } 10 \text { years. } \\
\text { The reform was announced and took effect in } 1961 \text { affecting those in the eighth grade } \\
\text { and below at that time. Since the school starting age was } 6 \text { at the time, we omit those } \\
\text { born in } 1947 \text { (i.e. 1961-8-6). }\end{array}$ \\
\hline IE & $\begin{array}{l}\text { C: } 1953-1957 \\
\text { T: } 1959-1963\end{array}$ & $\begin{array}{l}\text { The School Attendance (Amendment) Act of } 1967 \text { extended the duration of Ireland's } \\
\text { compulsory schooling from } 8 \text { to } 9 \text { years. The reform was announced in } 1967 \text { but only } \\
\text { became effective } 5 \text { years later in April 1972. Since Irish children started school at the } \\
\text { age of } 6 \text { at the time, we exclude individuals born in } 1958 \text { (i.e. 1972-8-6). }\end{array}$ \\
\hline IL & $\begin{array}{l}\text { C: } 1949-1953 \\
\text { T: } 1955-1959\end{array}$ & $\begin{array}{l}\text { In Israel, the duration of compulsory schooling was raised from } 9 \text { to } 11 \text { years by the } \\
\text { Compulsory Education (Amendment) Law of } 1968 \text {. The reform became effective in } \\
\text { the same year affecting those in the eighth grade and below at that time (the previous } \\
\text { compulsory education included one year of public kindergarten). Since Israel's school } \\
\text { starting age was } 5 \text { at the time, we omit those born in } 1954 \text { (i.e. 1968-9-5). }\end{array}$ \\
\hline IS & $\begin{array}{l}\text { C: } 1965-1969 \\
\text { T: } 1971-1975\end{array}$ & $\begin{array}{l}\text { The length of compulsory schooling in Iceland was raised from } 7 \text { to } 9 \text { years by the } \\
\text { Compulsory Education Act of } 1974 \text {. However, the implementation of this reform was } \\
\text { postponed until } 1984 \text {. Since Iceland's school starting age was } 7 \text { at the time, we exclude } \\
\text { those born in } 1970 \text { (i.e. 1984-7-7). }\end{array}$ \\
\hline IT & $\begin{array}{l}\text { C: } 1948-1952 \\
\text { T: } 1954-1958\end{array}$ & $\begin{array}{l}\text { The Law No. } 1859 \text { of } 31 \text { December } 1962 \text { extended the duration of Italy's compulsory } \\
\text { schooling from } 5 \text { to } 8 \text { years. The reform was implemented in } 1964 \text { affecting those in } \\
\text { the fifth grade and younger at that time. Since Italy's school starting age was } 6 \text { at the } \\
\text { time, we omit individuals born in } 1953 \text { (i.e. 1964-5-6). }\end{array}$ \\
\hline JP & $\begin{array}{l}\text { C: } 1933-1937 \\
\text { T: } 1939-1943\end{array}$ & $\begin{array}{l}\text { In Japan, the Fundamental Law of Education of } 1947 \text { required all children to complete } \\
\text { secondary education by raising the duration of compulsory schooling from } 6 \text { to } 9 \text { years. } \\
\text { The reform only became effective in } 1950 \text { as the development of the curriculum for } \\
\text { secondary education was completed. Since Japan's school starting age was } 6 \text { at the } \\
\text { time, we drop individuals born in } 1938 \text { (i.e. 1950-6-6). }\end{array}$ \\
\hline $\mathrm{KR}$ & $\begin{array}{l}\text { C: } 1968-1972 \\
\text { T: } 1974-1978\end{array}$ & $\begin{array}{l}\text { According to the Elementary and Secondary Education Act, the length of compulsory } \\
\text { schooling in Korea increased from } 6 \text { to } 9 \text { years. The reform became effective in the } \\
\text { same year affecting those in the sixth grade and below at that time. Since Korea's } \\
\text { school starting age was } 6 \text { at the time, we omit those born in } 1973 \text { (i.e. 1985-6-6). }\end{array}$ \\
\hline NL & $\begin{array}{l}\text { C: } 1954-1958 \\
\text { T: } 1960-1964\end{array}$ & $\begin{array}{l}\text { In Netherland, the Secondary Education (Amendment) Acts of } 1975 \text { extended the } \\
\text { length of compulsory schooling from } 9 \text { to } 10 \text { years. The reform required students born } \\
\text { on or after August } 1,1959 \text {, to complete } 10 \text { years of compulsory education. Therefore, } \\
\text { we simply exclude individuals born in } 1959 \text {. }\end{array}$ \\
\hline NO & $\begin{array}{l}\text { C: } 1986-1990 \\
\text { T: } 1992-1996\end{array}$ & $\begin{array}{l}\text { According to the Reform } 97 \text { of } 14 \text { November 1996, the length of compulsory schooling } \\
\text { in Norway was raised from } 9 \text { to } 10 \text { years by lowering the school starting age from } 7 \text { to } \\
\text { 6. The reform became effective on August 1, 1997. Therefore, we drop individuals } \\
\text { born in } 1991 \text { (i.e. } 1997-0-6 \text { ). }\end{array}$ \\
\hline
\end{tabular}




\begin{tabular}{|c|c|c|}
\hline Country & Cohorts & Description \\
\hline $\mathrm{NZ}$ & $\begin{array}{l}\text { C: } 1953-1957 \\
\text { T: } 1959-1963\end{array}$ & $\begin{array}{l}\text { The Education Act } 1964 \text { extended the duration of New Zealand's compulsory schooling } \\
\text { from } 8 \text { to } 9 \text { years by lowering the school starting age from } 7 \text { to } 6 \text {. The reform took } \\
\text { effect in the same year affecting those in starting their first grade at that time or later. } \\
\text { Thus, we exclude individuals born in } 1958 \text { (i.e. 1964-0-6). }\end{array}$ \\
\hline PL & $\begin{array}{l}\text { C: } 1947-1951 \\
\text { T: } 1953-1957\end{array}$ & $\begin{array}{l}\text { The Educational System Development Act of July 15, 1961, extended the duration of } \\
\text { Poland's compulsory schooling from } 7 \text { to } 8 \text { years. While announced in 1961, the reform } \\
\text { took effect in } 1966 \text { affecting those in the seventh grade and below at that time. Since } \\
\text { the school starting age was } 7 \text { at the time, we omit those born in } 1952 \text { (i.e. 1966-7-7). }\end{array}$ \\
\hline $\mathrm{PT}$ & $\begin{array}{l}\text { C: } 1952-1956 \\
\text { T: } 1958-1962\end{array}$ & $\begin{array}{l}\text { The Decree-Law No. } 45810 \text { of July } 9,1964 \text {, extended the duration of Portugal's } \\
\text { compulsory schooling from } 4 \text { to } 6 \text { years. According to the law, those starting their } \\
\text { first grade in } 1964 \text { was not allowed to leave school before turning } 13 \text {. Since Portugal's } \\
\text { school starting age was } 7 \text { at the time, we omit individuals born in } 1957 \text { (i.e. 1964-0-7). }\end{array}$ \\
\hline $\mathrm{SE}$ & $\begin{array}{l}\text { C: } 1946-1950 \\
\text { T: } 1952-1956\end{array}$ & $\begin{array}{l}\text { In } 1962 \text {, the Comprehensive School Code } 1962: 439 \text { raised the duration of Sweden's } \\
\text { mandatory schooling from } 8 \text { to } 9 \text { years. The reform required those in fifth grade at the } \\
\text { implementation time to stay in school for } 9 \text { years. The earliest birth cohort subject to } \\
\text { the law was those in the fifth grade in } 1963 \text {. Thus, we exclude those born in } 1951 \text { (i.e. } \\
\text { 1963-5-7), given that the school starting age was } 7 \text { at the time. }\end{array}$ \\
\hline SR & $\begin{array}{l}\text { C: } 1976-1980 \\
\text { T: } 1982-1986\end{array}$ & $\begin{array}{l}\text { According to Suriname Constitution of } 1987 \text {, compulsory education was introduced } \\
\text { in Suriname for the first time requiring all children to stay in school for } 6 \text { years of } \\
\text { primary education. The reform became effective in the same year affecting those } \\
\text { starting their first grade at that time or later. Therefore, we omit those born in } 1981 \\
\text { (i.e. 1987-0-6), given that the school starting age was } 6 \text { at the time. }\end{array}$ \\
\hline $\mathrm{TH}$ & $\begin{array}{l}\text { C: } 1963-1967 \\
\text { T: } 1969-1973\end{array}$ & $\begin{array}{l}\text { The duration of compulsory schooling in Thailand was raised from } 4 \text { to } 6 \text { years by the } \\
\text { Primary Education Curriculum of } 1978 \text {. The reform became effective in the same year } \\
\text { affecting those in the fourth grade and younger at that time. Since Thailand's school } \\
\text { starting age was } 6 \text { at the time, we drop individuals born in } 1968 \text { (i.e. 1978-4-6). }\end{array}$ \\
\hline TW & $\begin{array}{l}\text { C: } 1957-1961 \\
\text { T: } 1963-1967\end{array}$ & $\begin{array}{l}\text { In Taiwan, for the first time, compulsory education was introduced by the Nine-Year } \\
\text { Compulsory Education Program of } 1968 \text {. The reform became effective in the same } \\
\text { year mandating that all children starting their first grade at that time or later must } \\
\text { complete } 9 \text { years of compulsory schooling. Since Taiwan's school starting age was } 6 \text { at } \\
\text { the time, we drop individuals born in } 1962 \text { (i.e. 1968-0-6). }\end{array}$ \\
\hline UY & $\begin{array}{l}\text { C: } 1956-1960 \\
\text { T: } 1962-1966\end{array}$ & $\begin{array}{l}\text { In } 1973 \text {, The Education Law } 14101 \text { was introduced extending the duration of Uruguay's } \\
\text { compulsory schooling from } 6 \text { to } 9 \text { years. The reform became effective in the same year } \\
\text { affecting those in the sixth grade and below at that time. Since Uruguay's school } \\
\text { starting age was } 6 \text { at the time, we exclude those born in } 1961 \text { (i.e. 1973-6-6). }\end{array}$ \\
\hline $\mathrm{ZA}$ & $\begin{array}{l}\text { C: } 1985-1989 \\
\text { T: } 1991-1995\end{array}$ & $\begin{array}{l}\text { The South African Schools Act of } 1996 \text { stipulated compulsory education for } 9 \text { years } \\
\text { to all children in the country for the first time. The reform became effective in the } \\
\text { same year affecting those starting their first grade or younger at that time. Since the } \\
\text { school starting age was } 6 \text { at the time, we drop South African children born in } 1990 \\
\text { (i.e. 1996-0-6). }\end{array}$ \\
\hline
\end{tabular}




\begin{tabular}{|c|c|c|}
\hline Country & Cohorts & Description \\
\hline GB & $\begin{array}{l}\text { For England } \\
\text { \& Wales: C: } \\
\text { 1952-1956 T: } \\
\text { 1958-1962 For } \\
\text { Scotland: C: } \\
\text { 1956-1960 T: } \\
\text { 1962-1966 }\end{array}$ & $\begin{array}{l}\text { According to the Raising of the School Leaving Age Order 1972, the length of compul- } \\
\text { sory schooling in Great Britain was extended from } 10 \text { to } 11 \text { years. While the reform } \\
\text { took effect immediately in England and Wales, it was delayed until } 1976 \text { in Scotland. } \\
\text { Since students start school at the age of } 5 \text { in Great Britain, we omit those born in } \\
1957 \text { (i.e. 1972-10-5) for England and Wales and in } 1961 \text { (i.e. 1976-10-5) for Scotland. } \\
\text { Therefore, in England and Wales, the control and treatment groups are [C: 1952-1956] } \\
\text { and [T: 1958-1962]. In Scotland, the control and treatment groups are [C: 1956-1960] } \\
\text { and [T: 1962-1966]. }\end{array}$ \\
\hline CS & $\begin{array}{l}\text { C: } 1964-1968 \\
\text { T: } 1970-1974\end{array}$ & $\begin{array}{l}\text { Passed on March } 22,1984 \text {, the Act No. } 29 / 1984 \text { of the Law Code extended the length } \\
\text { of compulsory schooling from } 9 \text { to } 10 \text { years in Czechoslovakia, including Czech (CZ) } \\
\text { and Slovakia (SK) in our sample. The reform became effective in the same year } \\
\text { affecting those in the ninth grade and younger at that time. Since Czechoslovakia's } \\
\text { school starting age was } 6 \text { at the time, we drop individuals born in } 1969 \text { (i.e. 1984-9-6). }\end{array}$ \\
\hline YU & $\begin{array}{l}\text { C: } 1929-1933 \\
\text { T: } 1935-1939\end{array}$ & $\begin{array}{l}\text { In Yugoslavia, including Croatia (HR) and Slovenia (SI) in our sample, the duration of } \\
\text { compulsory schooling was raised from } 4 \text { to } 7 \text { years by the Federal Law on Elementary } \\
\text { Schools of } 26 \text { October } 1945 \text {. The reform became effective in the same year affecting } \\
\text { those in the fourth grade and younger at that time. Since Yugoslavia's school starting } \\
\text { age was } 7 \text { at the time, we exclude individuals born in } 1934 \text { (i.e. 1945-4-7). }\end{array}$ \\
\hline $\mathrm{SU}$ & $\begin{array}{l}\text { C: } 1950-1954 \\
\text { T: } 1956-1960\end{array}$ & $\begin{array}{l}\text { There are } 4 \text { countries in our sample that were part of the Soviet Union including } \\
\text { Georgia (GE), Latvia (LV), Lithuania (LT), and Russia (RU). Adopted in } 1961 \text { at } \\
\text { the } 22 \text { nd Congress, the third Program of the Communist Party of the Soviet Union } \\
\text { directed that the Universal Compulsory Secondary Education to be introduced in } 1970 \text {. } \\
\text { The goal was to provide mandatory } 11 \text { years of schooling for all children between the } \\
\text { ages of } 7 \text { and } 17 \text {. An amendment was passed later lowering the bar from } 11 \text { to } 10 \\
\text { years. Thus, the length of compulsory schooling was raised from } 8 \text { to } 10 \text { years in } 1970 \text {. } \\
\text { Since the school starting age was } 7 \text { at the time, we omit individuals born in } 1955 \text { (i.e. } \\
\text { 1970-8-7). }\end{array}$ \\
\hline
\end{tabular}

Note: $\mathrm{C}$ denotes the control group. T stands for the treatment group. We exclude individuals who were right at the age cut-off when the reforms took effect (focal cohort) because it is unclear whether these cohorts were exposed to the reforms. 
Table A2: Summary Statistics

\begin{tabular}{|c|c|c|c|c|}
\hline & Control & Treatment & All & Observations \\
\hline & (1) & $(2)$ & (4) & $(5)$ \\
\hline \multicolumn{5}{|l|}{ Panel A: Dependent Variables } \\
\hline Interest in Politics & $\begin{array}{c}0.315 \\
(0.464)\end{array}$ & $\begin{array}{c}0.309 \\
(0.462)\end{array}$ & $\begin{array}{c}0.312 \\
(0.463)\end{array}$ & 16,470 \\
\hline Knowledge of Politics & $\begin{array}{c}0.471 \\
(0.499)\end{array}$ & $\begin{array}{l}0.468 \\
(0.499)\end{array}$ & $\begin{array}{c}0.469 \\
(0.499)\end{array}$ & 14,484 \\
\hline Protesters' Public Meetings & $\begin{array}{c}0.850 \\
(0.357)\end{array}$ & $\begin{array}{c}0.866 \\
(0.340)\end{array}$ & $\begin{array}{c}0.858 \\
(0.349)\end{array}$ & 16,308 \\
\hline Protesters' Demonstrations & $\begin{array}{c}0.770 \\
(0.421)\end{array}$ & $\begin{array}{c}0.798 \\
(0.402)\end{array}$ & $\begin{array}{c}0.784 \\
(0.412)\end{array}$ & 16,220 \\
\hline Revolutionists' Public Meetings & $\begin{array}{c}0.512 \\
(0.500)\end{array}$ & $\begin{array}{c}0.538 \\
(0.499)\end{array}$ & $\begin{array}{c}0.525 \\
(0.499)\end{array}$ & 15,866 \\
\hline Revolutionists' Book Publications & $\begin{array}{c}0.621 \\
(0.485)\end{array}$ & $\begin{array}{c}0.642 \\
(0.480)\end{array}$ & $\begin{array}{c}0.632 \\
(0.482)\end{array}$ & 15,624 \\
\hline Vote & $\begin{array}{c}0.859 \\
(0.348)\end{array}$ & $\begin{array}{c}0.837 \\
(0.369)\end{array}$ & $\begin{array}{c}0.848 \\
(0.359)\end{array}$ & 10,416 \\
\hline Far-left & $\begin{array}{c}0.055 \\
(0.229)\end{array}$ & $\begin{array}{c}0.055 \\
(0.228)\end{array}$ & $\begin{array}{c}0.055 \\
(0.228)\end{array}$ & 12,038 \\
\hline Center-left & $\begin{array}{c}0.289 \\
(0.453)\end{array}$ & $\begin{array}{c}0.284 \\
(0.451)\end{array}$ & $\begin{array}{c}0.286 \\
(0.452)\end{array}$ & 12,038 \\
\hline Center & $\begin{array}{c}0.220 \\
(0.414)\end{array}$ & $\begin{array}{c}0.197 \\
(0.398)\end{array}$ & $\begin{array}{c}0.209 \\
(0.406)\end{array}$ & 12,038 \\
\hline Center-right & $\begin{array}{c}0.251 \\
(0.433)\end{array}$ & $\begin{array}{c}0.244 \\
(0.429)\end{array}$ & $\begin{array}{c}0.247 \\
(0.431)\end{array}$ & 12,038 \\
\hline Far-right & $\begin{array}{c}0.024 \\
(0.154)\end{array}$ & $\begin{array}{c}0.028 \\
(0.164)\end{array}$ & $\begin{array}{c}0.026 \\
(0.159)\end{array}$ & 12,038 \\
\hline \multicolumn{5}{|l|}{ Panel B: Explanatory Variables } \\
\hline Years of Education & $\begin{array}{l}11.70 \\
(3.915)\end{array}$ & $\begin{array}{c}12.17 \\
(3.796)\end{array}$ & $\begin{array}{c}11.94 \\
(3.863)\end{array}$ & 17,429 \\
\hline Age & $\begin{array}{c}51.77 \\
(11.91)\end{array}$ & $\begin{array}{c}48.46 \\
(10.95)\end{array}$ & $\begin{array}{c}50.12 \\
(11.56)\end{array}$ & 17,429 \\
\hline Male & $\begin{array}{c}0.450 \\
(0.498)\end{array}$ & $\begin{array}{c}0.461 \\
(0.498)\end{array}$ & $\begin{array}{c}0.455 \\
(0.498)\end{array}$ & 17,429 \\
\hline Married & $\begin{array}{c}0.672 \\
(0.469)\end{array}$ & $\begin{array}{c}0.695 \\
(0.461)\end{array}$ & $\begin{array}{c}0.683 \\
(0.465)\end{array}$ & 17,429 \\
\hline Household Size & $\begin{array}{c}3.014 \\
(1.606)\end{array}$ & $\begin{array}{c}3.179 \\
(1.578)\end{array}$ & $\begin{array}{c}3.096 \\
(1.594)\end{array}$ & 17,429 \\
\hline Big City & $\begin{array}{c}0.283 \\
(0.451)\end{array}$ & $\begin{array}{c}0.278 \\
(0.448)\end{array}$ & $\begin{array}{c}0.281 \\
(0.449)\end{array}$ & 17,429 \\
\hline Public Employer & $\begin{array}{c}0.225 \\
(0.418)\end{array}$ & $\begin{array}{c}0.212 \\
(0.409)\end{array}$ & $\begin{array}{c}0.218 \\
(0.413)\end{array}$ & 17,429 \\
\hline
\end{tabular}


Figure A1: Impacts of Compulsory Schooling Laws on Educational Attainment

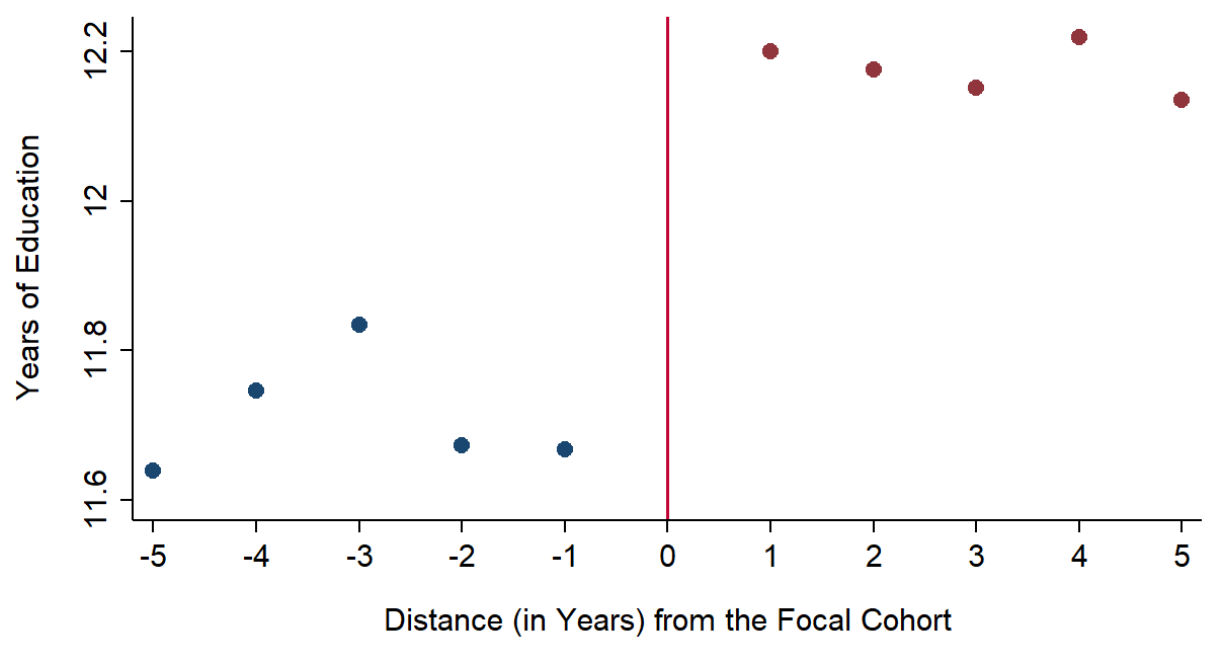

Note: The horizontal axis gives the distance between individual birth year and the birth year of the focal cohort. The vertical axis presents the average years of education of each cohort. 